Jurnal Jeumpa, 7 (1) Januari - Juni 2020

\title{
PERBEDAAN HASIL BELAJAR SISWA DENGAN MENGGUNAKAN MODEL STUDENT TEAM ACHIVEMENT DIVISION (STAD) DAN NUMBERED HEAD TOGETHER (NHT) PADA MATERI STRUKTUR DAN FUNGSI JARINGAN TUMBUHAN KELAS VIII DI SMP N 6 LANGSA TAHUN PELAJARAN 2019/2020
}

\author{
Kartini $^{1}$, Nursamsu ${ }^{2}$, Sofiyan $^{3}$ \\ Jurusan Pendidikan Biologi Fakultas Keguruan Dan Ilmu Pendidikan \\ Universitas Samudra \\ Email : kartinironal@gmail.com
}

\begin{abstract}
ABSTRAK
Pendidikan adalah proses pengubahan sikap dan prilaku seseorang atau kelompok yang dalam usaha mendewasakan diri melalui upayah pengajaran dan pendidikan, ketika membahas mengenai pendidikan, kebanyakan orang cenderung berpikir mengenai sekolah atau perguruan tinggi, padahal pengertian pendidikan tidakhanya berkaitan dengan sekolah, akan tetapi juga menyangkut akan hasil nilia siswa. Penelitian ini bertujuan untuk mengetahui perbedaan hasil belajar siswa dan model manakah yang lebih baik terhadap hasil belajar yang menggunakan model Student Team Achievement Division (STAD) dan Numbered Head Together (NHT) yang mengunakan materi struktur dan fungsi jaringan tumbuhan kelas VIII di SMP N 6 Langsa tahun pelajaran 2019/2020. Metode yang di gunakan adalah metode eksperimen dengan intrumen berupa tes tulis. Hasil yang diperoleh membuktikan bahwa ada perbandingan model Student Team Achievement Division (STAD) dengan Numbered Head Together terhadap hasil belajar siswa kelas VIII di SMP N 6 Langsa tahun pelajaran 2019/2020, dengan adanya kriteria pengujian $-t_{1-\frac{1}{2} \alpha}<t<t_{1-\frac{1}{2} \alpha}$ dengan nilai $-2,008-0,025 \leq 5,97 \leq 2,008-0,025$ sama dengan $-2,033 \leq 5,79 \leq 1,983$. Dengan selisih perbandingan hasil belajar sebesar 2,46. Materi struktur dan fungsi jaringan tumbuhan kelas VIII di SMP N 6 Langsa tahun pelajaran 2019/2020.
\end{abstract}

Kata Kunci : STAD, NHT, Struktur Dan Fungsi Jaringan Dan Tumbuhan, Dan Hasil Belajar

\section{ABSTRACT}

Education is the process of changing the attitudes and behavior of a person or group who in an effort to mature themselves through teaching and education efforts, when talking about education people will tend to think about school or tertiary education, even though the notion of education is not only related to school, but also regarding grades students. This study aims to determine differences in student learning outcomes and which model is better for learning outcomes using the Student Team Achievement Division (STAD) and Numbered Head Together (NHT) models on the structure and function material of plant networks in class VIII at SMP N 6 Langsa. 2019/2020 lessons. The method used is an experimental method with instruments in the form of written tests. The results obtained prove that there is a comparison of the Student Team Achievement Division (STAD) model with Numbered Head Together on the learning outcomes of class VIII students at SMP N 6 Langsa in the 2019/2020 school year, with the testing criteria - $t_{-}(1-1 / 2 \alpha)<t<t_{-}(1-1$ 
Jurnal Jeumpa, 7 (1) Januari - Juni 2020

/ $2 \alpha)$ with a value of $-2.008-0.025 \leq 5.97 \leq 2.008-0.025$ is the same as $-2.033 \leq 5.79 \leq 1.983$. With a difference in the comparison of learning outcomes of 2.46. Material for the structure and function of plant tissue for class VIII at SMP N 6 Langsa in the 2019/2020 school year.

Keywords: STAD, NHT, Plant and Network Structure and Function, and Learning Outcomes

\section{PENDAHULUAN}

Pendidikan merupakan proses penggantian sikap dan prilaku dalam mengedewasakan diri seseorang melalaui upaya pendidikan. Ketika membahas mengenai pendidikan, kebanyakan orang cenderung berpikir mengenai sekolah atau perguruan tinggi, padahal memahami pendidikan tidak hanya mengani sekolah saja, akan tetapi juga menyakut akan hasil nilai belajar siswa tersebut, seperti melakukan kegiatan dalam dunia pendidikan, salah satunya menyertakan aspek pembelajaran. Pembelajaran merupakan upayah pendidik dalam membantu siswa melakukan kegiatan belajar agar efisiensi serta efektif dalam memperoleh pembelajaran yang dilakukan siswa (Isjoni, 2013:2014).

Maka dari itu penggunaan model pembelajaran sangat pengaruh terhadap hasil belajar siswa, dikarenakan bukan cuma guru saja yang aktif namun siswa juga aktif dalam bimbingan tersebut. Proses pembelajaran di SMP N 6 Langsa mesih mengalami beberapa masalah, seperti aktifitas siswa selama kegiatan belajar mengajar hanya terfokus kepada guru saja yang mengakibatkan hasil nilai siswa yang diperoleh mesih rendah. Untuk itu perlu diatasi agar siswa dapat memperoleh nilai yang tinggi, salah satunya dengan merubah cara pembelajaran agar lebih menarik bagi siswa seperti model $N H T$ dan STAD yang cocok untuk pembelajaran IPA-Biologi.

Menurut (Shoimin, 2014:107) mengunakan "Model Numbered Heads Together mengarah kepada kelompok belajar siswa yang memiliki bagian tugasnya masing-masing dengan nomor kepala yang berbeda-beda". Menurut (Istarani, 2014:13) kelebihan dari numbered head together yakni

1. Meningkat kan kerja sama diantara siswa dalam kelompok

2. Dapat meningkatkam tanggung jawab siswa secara bersama

3. Dapat menyatukan pemikiran para siswa

4. Melatih siswa untuk menghargai pendapat orang lain

Menurut (Istarani, 2014:16) menyatakan bahwa "model pembelajaran 
Jurnal Jeumpa, 7 (1) Januari - Juni 2020

Student Team Achievement Divisison (STAD) adalah suatu strategi pembelajaran yang memiliki kemampuan yang berbeda dalam sebuah perkumpulan belajar yang terdiri dari 4-5 dalam satu kelompok". (Shoimin, 2014:189) juga menyatakan yang menjadi kelebihan dari model pembelajaran STAD adalah "meningkatkan kerja sama siswa, menumbuhkan rasa saling membantu antar sesame, dimana siswa yang lebih mampu membantu temannya yang kurang mampu, meningkatkan kepercaan diri dan tidak memiliki sifat bersaing.

Pelaksanaan model pembelajaran yang tepat akan membuat hasil belajar siswa lebih baik. Menurut (Sudjana, 2005:22) “ Hasil belajar pada kapasitas yang dimiliki siswa akan diperoleh setelah menerima pengalaman belajar". Adapun tujuan yang diinginkan adalah untuk memperoleh perbandingan hasil belajar pada siswa kelas VIII antara model student Team Acievement Division (STAD) dengan Numbere Heat together (NHT) yang mengunakan materi struktur dan fungsi jaringan tumbuhan kelas VIII di SMP 6 Kota Langsa Tahun pelajaran 2019 / 2020 dan untuk mengetahui perbedaan mana yang lebih baik pada hasil belajar siswa kelas VIII yang menggunakan model Student Team Achievement Division (STAD) dengan Numbered Head Together (NHT) pada
Struktur dan Fungsi Jaringan Tumbuhan pada kelas VIII di SMP N 6 Langsa Tahun Pelajaran 2019/2020.

\section{METODE PENELITIAN}

\section{Waktu dan Tempat}

Pengamatan dilaksanakan di SMP N 6 Langsa yang terletak di Jln. Perumnas Kota Langsa, Kec. Langsa Baroe. Pada Bulan Juli 2019

\section{Populasi}

Populasi yang diamati adalah seluruh siswa kelas VIII di SMP N 6 Langsa dengan keseluruhan siswa 63 orang. Data dapat di lihat pada tabel berikut:

Tabel 1. Populasi siswa kelas VIII di SMP N6 Langsa

\begin{tabular}{|c|c|c|c|}
\hline Kelas & Laki-laki & Perempuan & Jumlah \\
\hline VIII- 1 & 8 & - & 8 \\
\hline VIII-2 & 11 & 16 & 27 \\
\hline VIII-3 & 17 & 11 & 28 \\
\hline Jumlah & $\mathbf{3 6}$ & $\mathbf{2 7}$ & $\mathbf{6 3}$ \\
\hline
\end{tabular}

(Sumber: Tata Usaha SMP N 6 Langsa )

\section{Sampel Penelitian}

Dalam penelitian ini sampel di ambil bertujuan dikarenaka jumlah siswa hetorogen, maka terdapatlah siswa kelas VIII2-VIII 3 sebagai sampel. Dimana pada 
Jurnal Jeumpa, 7 (1) Januari - Juni 2020

kelas VII-2 menggunakan model pembelajaran Student Team Achievement Division (STAD) dan pada kelas VIII-3 memakai model Numbered Head Together. Data sampel dapat dilahat pada tabel 1.

\section{Instrumen Penelitian}

Intrumen pada penelitian ini adalah tes tertulis dengan pilihan jawaban ganda yaitu dengan pilihan jawaban a, b, c, dan d sebanyak 20 soal. Tes ini dilakukan saat pretes dan postes

\section{HASIL DAN PEMBAHSAN}

Berdasarkan pengamatan hasil nilai siswa kelas VIII-2 di aplikasih dengan cara student team achievement division sebesar 66,84 dan siswa kelas VIII-3 dengan numbered head together 64,38. Maka dengan demikian selisih nilai antara keduanya adalah 2,46 . Berdasarkan nilai yang di peroleh maka model $S T A D$ memiliki nilai belajar yang lebih dalam pembelajaran dari pada model NHT dengan mengunakan materi struktur dan fungsi jaringan tumbuhan kelas VIII di SMP N 6 Langsa tahun pelajaran 2019/2020.

Dari hasil tersebut dapat diketahui bahwa model Student Team Achievement Division dengan Numbered Heat Together memberikan perbedaan mengenai hasil belajar siswa. Dikarenakan masing-masing model pembelajaran memiliki langkah langkah pembelajaran yang berbeda. Dimana Mawardi (2011) menyatakan "model NHT dan STAD digunakan sebagai media pembelajaran memenglah tidak sma, namun mempunyai satu sisi yang sebanding yaitu , difokuskan kepada aktifitas siswa untuk bekerja sama.

Meskipun kedua model tersebut memimiliki sedikit kesamaan jika kita melihat lagi pada hasil akhir analisis data dimana dimana model pembelajaran stad lebih unggul dari nht, di mana Edi dkk (2009) mengungkapkan bahwa " model STAD dapat membuat siswa lebih paham akan materi yang di pelajari karena adanya dukungan diantara siswa dalam kelompok sehingga siswa lebih memahami konsep yang sulit”. Hal ini juga di ungkap oleh (Hamdani, 2011:93) menyatakan STAD sebagai sebuah model pembelajaran dengan "mengelompokan siswa secara hetorogen kemudian siswa yang pandai menjelaskan pada amggota yang lain sampai mengerti”. Maka dengan demikian dapat kita ambil dimana anak yang lebih pandai mengajarkan temenya sampai mengerti maka disini terjadihlah sebuah penukaran pikiran yang yang mana dapat memebuat satu sama lain dalam memecahkan sebuah masalah untuk 
Jurnal Jeumpa, 7 (1) Januari - Juni 2020

menjawab soal yang di berikan oleh guru kepada setiap kelompok.

Berbeda dengan NHT dimana model pembelajaran ini lebih memgutamakan tugas individu meski berada pada satu kelompok yang sama. Numbered Head Together ialah suatu pemebelajaran yang mengutamakan aktifitas siswa dalam mencari informasi dari berbagai referensi sumber pada akhirnya dipersentasikan didepan kelas sesuai dengan urutan nomor yang ada dikepala setiap anak untuk maju kedepan kelas. Menurut (Trianto, 2010) "Model Numbered Head Together mengacu pada belajar kelompok siswa. Masing -masing anggota memiliki bagian tugas (pertanyaan) dengan nmor yang berbeda -beda". Dimana siswa lebih terfokus pada diri sendiri apabila telah siap mengerjakannya atau memecahakan soal yang di berikan oleh guru kepada murid. Maka dapat kita simpulkan bahwa model pembelajaran stad lebih berhasil dari model NHT dikarenakan hasil nilai yang di peroleh oleh stad lebih unggul dari pada model NHT terhadap memecahkan masalah.

\section{KESIMPULAN}

Berdasarkan pengamatan yang telah di lakukan peneliti dapat penyimpulkan bahwa ada perbedaan model Student Team Achievement Division (STAD) dan Numbered
Head Together (NHT) dengan percobaan mengunakan materi struktur dan fungsi jaringan tumbuhan mengunakan kelas VIII di SMP N 6 Langsa tahun pelajaran 2019/2020.

Selisih perbandingan nilai yang didapat pada model Student Team Achievement Division (STAD) dengan Numbered Head Together (NHT), berkisaran 2,46 antara 64,38 ke 66,84 yang diperoleh.

\section{DAFTAR PUSTAKA}

Edi. S. S. Hartono, Nugroho U. 2009, Penerapan Pembelajaran Kooperatif Tipe STAD Berrorientasi Keterampilan Proses, Jurnal Pendidikan Fisika (5) : 107-111

Hamdani. 2011. Strategi Belajar Mengajar, Bandung : Pustaka Setia.

Isjoni, 2013. 58 Model Pembelajaran Inofatif, Medan : Media Persada.

Mawardi, Kusumawati, H. (2011). Perbedaan Penerapan Model Pembelajaran Kooperatif Tipe NHT Dan SATD Ditinjau Dari Hasil Belajar Siswa, Jurnal Pendidikan Guru Sekolah Dasar, 5(2) : 251-263

Shoimin, A. 2014. 68 Model Pembelajaran Inofatif Dalam Kurikulum 2013, Yogyakarta : Ar- Ruzz Media. 
Jurnal Jeumpa, 7 (1) Januari - Juni 2020

Sudjana, N. 2005. Penilaian Hasil Belajar Proses Belajar Mengajar, Bandung : Remaja Rosdakarya.
Trianto, 2010. Mendisian Model Pembeljaran Inofatif Progresif. Jakarta : Kencana Predana Media Group. 